\title{
Technical Profile on the Production of Pozzolana (An Emerging Construction Material) in Nigeria
}

\author{
Ekele A. Ogwu, Friday I. Apeh, Angela A. Ogwu, Babatunde S. Yahaya \\ Nigerian Building and Road Research Institute, Ota, Ogun State, Nigeria \\ Email: ekeleogwu@gmail.com
}

How to cite this paper: Ogwu, E.A., Apeh, F.I., Ogwu, A.A. and Yahaya, B.S. (2019) Technical Profile on the Production of Pozzolana (An Emerging Construction Material) in Nigeria. Open Journal of Civil Engineering, 9, 356-366.

https://doi.org/10.4236/ojce.2019.94024

Received: September 9, 2019

Accepted: December 23, 2019

Published: December 26, 2019

Copyright $\odot 2019$ by author(s) and Scientific Research Publishing Inc. This work is licensed under the Creative Commons Attribution International License (CC BY 4.0).

http://creativecommons.org/licenses/by/4.0/

\begin{abstract}
Pozzolana which is an eco-friendly and cheap supplementary cementious material has not been established on a commercial scale in the construction industry in Nigeria. Hence, this paper is aimed at presenting a feasibility study to show the viability and highlight the business opportunities available for local and foreign investors in the area of pozzolana production in Nigeria. The paper discussed the technical requirements and estimated start-up capital for setting up a Pozzolana production plant from calcinated of Fifteen Thousand Tonnes Annual Production Capacity. An outline for start-up capital identified building and civil work, furniture and fixtures, machinery and equipment requirement, intangible assets, and seed fund. Raw materials/utilities and organizational requirement for annual production were also presented. The investment is viable with a total investment cost of $\$ 507,321.23$, annual net profit of $\$ 107,961.70$ and a payback period of 4.7 years. The net profit ratio and rate of return are $16.28 \%$ and $21.28 \%$ respectively. The findings and understanding of the technical and financial requirements from this work will aid investors in making decisions. The project if carried out will reduce cement contents in concrete and mortar structures, with eco-friendly cement admixtures and subsequently reduce the cost of construction in general.
\end{abstract}

\section{Keywords}

Pozzolana, Technical Feasibility, Technical Requirements, Civil Work, Calcinated Clay, Utilities

\section{Introduction}

Concrete is a crucial material for infrastructural development. Its versatility and 
flexibility in usage and application make it superior to other building materials such as wood and steel [1]. Concrete is considered the most widely used construction material in the world. Portland cement (PC) is one of the major inputs in concrete. [2] identified major brands of cement used in Nigeria for concreting, which includes Dangote, Eagle, Ibeto and Elephant. Cost of cement production and its environmental concerns have led researchers to develop other binders for construction works. According to [3], concrete production contributes $5 \%$ of the annual global $\mathrm{CO}_{2}$ emissions of which the bulk is from the production of cement. Some of the binders used before the emergence of PC are clay, lime bitumen, pozzolans [2]. The global trend is researching into the reduction of the Portland cement contents in the concrete mixtures with cheaper Supplementary Cementitious Materials (SCM) to improve certain properties of concrete. [4] classified SCM as hydraulic and pozzolanic; this classification is based on their reacting mechanisms. Blended Cements are more common in Europe and South America and are generally less expensive than cement [4].

Pozzolans which can partially replace PC were defined by [5] as siliceous or siliceous and alumnus materials in which in themselves have little or no cementitious property but which will in finely divided form and in the presence of water react chemically with calcium hydroxide at room temperature to form compounds having cementitious properties. The measure of capacity of a pozzolana to react with calcium hydroxide and water is given by measuring its pozzolanic activity [6].

Pozzolans have historical evidence dating back as $500-400$ BC. The Greeks followed by the Romans in the pre- $400 \mathrm{BC}$ were the first civilizations to use pozzolana in lime motars. The ancient Greeks deliberately used volcanic materials, such as, volcanic ashes or tuffs [7]. This was uncovered at the ancient city of Kameiros, Rhodes, Greece. Pozzolana was used in Rome which made their concrete structure to withstand weathering [8]. In Europe, Asia and America, the application of Pozzolanic cements has been established. According to [2] developed countries have started wide production of these alternative binders and have developed standards for their applications. In recent times, more than 100,000 tons of pozzolana was used to construct the Los Angeles aqueduct. Particularly in Europe, North America and Japan, many mass concrete and marine structure, such as, dams and harbors have been constructed using pozzolana.

In developing countries, commercial exploitation of pozzolana is at a slower pace. In Africa, Ghana has acknowledged the use of Pozzolanic cements where the Building and Road Research Institute, BRRI in Ghana established a Pilot Plant in Ashanti City of Kumasi, likewise in Rwanda and the United Republic of Tanzania. In Nigeria, the use of pozzolana in commercial scale have not been acknowledged in spite of the great potentials, though, research works have been carried out extensively on the use of pozzolana. [9] identified eight (8) pozzolanic materials from agricultural by-products in Nigeria, these are; rice husk ash (RHA), Saw Dust Ash (SDA), Oil Palm Bunch Ash (OPBA), Cassava Waste Ash 
(CWA), Coconut Husk Ash (CHA), Corn Cob Ash (CCA), Plantain leaf Ash (PLA), and Pawpaw Leaf Ash (PPLA). As a result of large pozzolanic materials dispersed throughout the country, a pilot plant to meet a demand of 2 tonnes per day was built and test run by the Nigerian Building and road research institute (NBRRI). The essence is to demonstrate the technology on a pilot scale hence, medium and large scale production plants can be built.

The aim of this paper is to present a technical profile which will further illustrate the viability of pozzolana production on a mini scale (15,000 ton per year). Production of cement or cementitious binders/admixtures on a medium scale according to [10] is one with a total installed capacity not exceeding 200 tons/day which utilizes one or more kilns for its operations. The case of setting up mini-plants is to utilize deposits of raw materials in dispersed areas. Such production plants allow participation of small local investors and thus help in building the local economy. Mini-plants also offer the following advantages:

- Less capital intensive;

- Short gestation period;

- Quick return of investment;

- Utilization of small deposits of raw materials;

- Attractive to entrepreneurs with limited financial resources.

This paper as well discusses the technical profile of Mini Scale Pozzolana production and reveals the business prospects available for local and international investors in the area of pozzolana production in Nigeria using clay.

\section{Product Description, Production Process and Application}

Pozzolans are defined as siliceous or siliceous and alumnus materials in which in themselves have little or no cementitious property but in a finely divided form and in the presence of water will react chemically with calcium hydroxide at room temperature to form compounds having cementitious properties [11]. Pozzolanas are used as partial replacement for cement for concrete and motar structures to reduce cost of production. Fully pozzolanic binder is now developed and have been reported by [2] by combining pulverized calcinated clay and calcium hydroxide $\left(\mathrm{Ca}(\mathrm{OH})_{2}\right)$ which is a byproduct of carbide after being used to generate acetylene.

Pozzolana production from calcinated clay can be divided into three major stages. Each of these stages has more than one operation. The first stage is raw material preparation which consists of clay crushing in order to loosen the lumped clay and palm kernel grinding to have powdered form of the palm kernel shells (PKS). The second stage is raw materials processing which involves mixing the crushed clay with the ground PKS at the appropriate proportion with the addition of water. The resulting mixture will be nodulized and dried in open air and then calcinating in a VSK. The optimum calcinating temperature is normally taken between 700 and 800 degree celsius. After calcination, it is ground in a ball mill. The third stage is metering and bagging. Figure 1 shows 
the flow chart for the process.

Pozzolans are used beneficially with either lime or/and OPC. Blending with OPC only allows for replacement of up to 50 percent. With lime, (lime: pozzolana) of 1:1 to $1: 4$ is possible depending on the quality of lime and pozzolana, and the end use of the mortar. Figure 1 shows the process chart for the operation.

\section{Methodology}

The methodology employed was a detailed study during the test run of the 2 tons per day pilot plant established at Ota, Ogun State South West Nigeria. This involved determination of plant area/layout and identification of different equipment and establishing the capacity and number. Material and utility requirement was also established and the required man power for running the plant. Then a market survey which involved location and cost of all the inputs. The established mini scale plant is proposed to produce 45 tons per day operating at 334 days per year to have an annual production of 15,000 tons per year.

\subsection{Resources Requirement}

The resources needed to set up a pozzolana plant are; land and building, raw materials, machinery, manpower and finance.

\subsubsection{Land}

Land for building the production plant should be close to the sources of raw materials. Pozzolanic clay materials are deposited in commercial in the South West of Nigeria. Kaolinite clay is available in Ajebo, Abeokuta (southwest Nigeria) Ayininuola and Adekitan, (2016) [12]. There is also evidence of palm kernel shell (PKS) in large quantity within the South West and South South of Nigeria.

A land of one acre is suitable for the industry, taking into account an open space for heavy duty trucks during offloading of materials and loading of finished products. Land can be acquired by purchase, a lease or rent. Considering South West Nigeria, the average value of such land with full documentation and

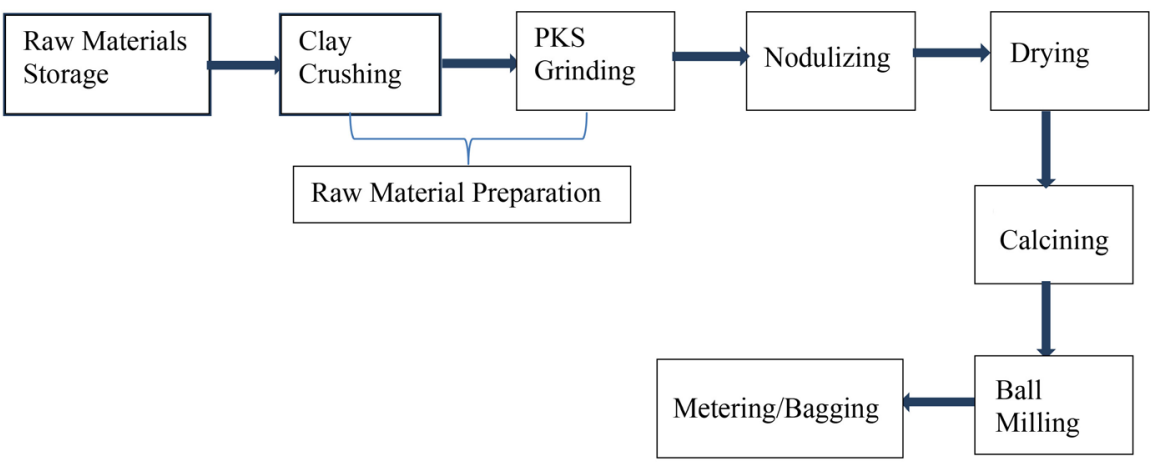

Figure 1. Process chart for the operation. 
Certificate of Ownership is put at $\$ 33,149.17$ (Land acquired from the community).

\subsubsection{Building/Civil Work/Electrical and Furniture}

The building is meant to be the processing area. It should have provision for offices, conference room and welfare facilities for the factory workers. Other spaces allocated include; canteen, changing and locker room. An estimated working area for the purpose of setting up a 15,000 ton annual pozzolana production plant is $30 \mathrm{~m} \times 60 \mathrm{~m}$. The total cost of building and civil work including is put at $\$ 207,182.32$. This includes landscaping, factory building, security post, fencing and power house. Office furniture is put at $\$ 13,812.15$.

\subsubsection{Materials and Inputs}

\section{1) Materials and Inputs}

The material resources to be used for the production in this work include; kaolinite clay, palm kernel shell and charcoal for firing the kiln and water. Table 1 shows the material requirements and cost for producing one tonne of pozzolana. Clay rich in kaolin is in abundant quantity in Ipokia, Moto-Yewa, Owode-Ketu and Abeokuta, both in Ogun State, South West Nigeria. Kaolinite clay is also in large exploitable quantity in Owerri in Imo State South East Nigeria, Niger State, Nassarawa State North Central Nigeria. Kebbi and Sokoto States North West Nigeria and in Bauchi State North East Nigeria. PKS is available in large quantity in Nigeria, according to [13], with Nigeria been the third largest producer of palm kernel shell after Malaysia and Indonesia. Water is an essential ingredient in any manufacturing and production outfit. Water is used in processing of materials and for proper welfare of staff in the factory. Water can be sourced from the State Water Cooperation or sinking of bore holes. A more sustainable source of water supply is the rainwater harvesting.

\section{2) Auxiliary Materials}

Material for packing the pozzolana is paper sack. This can be produced locally in a number of sack's producing companies in Nigeria. For annual production, 306,000 bags of $50 \mathrm{~kg}$ are required at the rate of $\$ 0.11$ per bag. Thus, annual expenditure for bags is estimated to be $\$ 33,812.2$.

Table 1. Material and utility requirements (Inputs and supplies) for annual production of pozzolana with costs.

\begin{tabular}{cccc}
\hline Material & Units & Quantity & Total Cost (\$) \\
\hline Clay & Tonnage & 11,250 & $247,612.5$ \\
PKS & Tonnage & 3750 & $36,262.5$ \\
Water & Liters & $4,729,020$ & $3,265.8$ \\
Charcoal & & & $34,530.4$ \\
Electricity & Kwh & 934,230 & $76,059.7$ \\
Total & & & $\mathbf{3 9 8 , 7 3 1 . 6}$ \\
\hline
\end{tabular}

$* * 40 \%$ of electricity cost added for office equipment. 


\subsubsection{Engineering/Technology}

The machine/equipment and tool requirement are:

1) Palm Kernel Shell Grinding Machine.

2) Clay Crusher (Rotary Mill).

3) Pelletizer.

4) Cup Conveyor.

5) Vertical Shaft Kiln.

6) Industrial Blower.

7) Ball Mill.

8) Screw Conveyor.

9) Metering and Bagging Facility.

10) Dust extractor.

11) Shovel.

12) Spade.

13) Wheel barrow.

14) Water spraying can.

15) Head pan.

16) Rake.

17) Metal bucket.

18) Scrapper.

The machines are electric motor driven apart from the kiln which is a refractory lined chamber with a metal jacket. The only foreign input is the metering and bagging facility. Every other equipment can be fabricated locally within the country and this would attract a cost reduction from freight and import charges. Table 2 presents the cost estimate of machines/ equipment needed.

\subsubsection{Organizational and Operational Requirement}

The manpower required in a pozzolana plant is the entire employee. It is important that all employees have defined roles and are qualified to take their respective responsibilities. The equipments used are easy to operate and operators need not to have too high educational background to operate the machines the basic requirement for the unskilled labour is fitness (physically and mentally). In a 45 ton per day plant the breakdown of the manpower is presented in Table 3.

\subsection{Legal and Professional Fees}

In Nigeria, the cooperate affairs commission is in charge of registering any business. Certain charges are involved in the process.

\subsection{Financing Options}

Finance is a very important resource for any business. Sources of funds could be personal savings, grants, issuance of shares or loans from financial institutions. Some of these institutions are commercial banks, cooperative societies and Bank of Industries. 
Table 2. List of machinery and equipment with cost.

\begin{tabular}{cccc}
\hline Machinery & Description/Capacity & Quantity & Total cost $(\$)$ \\
\hline $\begin{array}{c}\text { Palm kernel sheel } \\
\text { grinding machine } \\
\text { nodulizer }\end{array}$ & 0.625 ton/hr & 1 & 4143.6 \\
Hammer mill & 5 ton/h & 2 & 2762.4 \\
Cup elevator & 7.5 ton/h & 1 & 3314.0 \\
Vertical shaft kiln & 2 ton/h & 1 & 966.9 \\
Ball mill & 2 ton/h & 1 & $38,674.0$ \\
Bagging facility & $0-100 \mathrm{~kg}$ & 1 & 7596.7 \\
Working tools & & 1 & 4226.5 \\
Auxillary equipment & & & 303.9 \\
Total & & & $144,751.4$ \\
\hline
\end{tabular}

${ }^{*}$ Working tools are spades, shovels, rakes etc. ${ }^{* *}$ Auxiliary equipment includes electrical panels for machines, air compressor, $2 \mathrm{hp}$, water storage tank, dust extractor, vehicles $(\$ 110,497.2)$ and standby generator (250kVA@ @33,149.2).

Table 3. Manpower requirement for the plant.

\begin{tabular}{cccc}
\hline S/N & Description & Number & Labour cost (\$) \\
\hline 1 & Plant manager & 1 & 3314.90 \\
2 & Secretary & 1 & 1989.00 \\
3 & Clerk & 1 & 1490.70 \\
4 & Cashier & 1 & 2320.40 \\
5 & Salesperson & 1 & 1989.00 \\
6 & General service & 4 & 4640.90 \\
7 & Security & 8 & 9281.80 \\
8 & Foreman & 1 & 2983.40 \\
9 & Electrician/ mechanic & 2 & 3977.90 \\
10 & Machine operator & 3 & 4972.40 \\
11 & Labourer & 16 & $26,519.30$ \\
12 & Quality assurance personel & 1 & 2320.40 \\
13 & Prequisite @ 10\% salary & & 6353.60 \\
Total & & & $69,889.50$
\end{tabular}

\section{Results and Discussion}

\subsection{Investment}

\subsubsection{Fixed Cost}

The total fixed cost is presented in Table 4.

\subsubsection{Annual Working Capital}

The annual working capital is presented in Table 5 . 
Table 4. Total fixed cost.

\begin{tabular}{ccc}
\hline S/N & Item & Cost (\$) \\
\hline 1 & land & $33,149.17$ \\
2 & building and civil work & $207,182.32$ \\
3 & machine/Equipment & $63,093.92$ \\
4 & office furniture and fixture & $13,812.15$ \\
5 & intangible assets & $14,364.64$ \\
Total & & $\mathbf{3 3 9 , 5 0 2 . 7 6}$
\end{tabular}

${ }^{* *}$ Intangible assets includes interest during construction, training $(\$ 13,812.15)$ and $(\$ 552.48)$ costs of registration, licensing and formation of the company including legal fees, commissioning expenses, etc.

Table 5. Annual working capital.

\begin{tabular}{ccc}
\hline $\mathrm{S} / \mathrm{N}$ & Item & Cost \\
\hline 1 & Labour cost & $68,889.50$ \\
2 & Raw materials and utilities & $398,731.63$ \\
3 & Auxiliaries & $33,812.15$ \\
4 & Administrative and contingencies & 1022.10 \\
Total & & $503,455.39$ \\
\hline
\end{tabular}

**Administrative and contingencies includes vehicle fuelling and maintenance (\$331.49), postage \& telephones (\$331.49), advert and publicity (\$110.50), secretarial and paper work (\$55.25), miscellaneous (\$138.12).

\subsubsection{Total Capital Investment}

The total capital investment is the sum of fixed capital and working capital for the quarter of production year. Table 6 presents the total capital investment.

Table 4 presents the fixed cost which amounted to $\$ 339,502.76$. Items from the fixed cost include land and civil work, machinery and equipment, office furniture and fixtures and intangible assets. The percentages of the various items in the fixed cost are; $9.8 \%, 61 \%, 18.6 \%, 6.2 \%$ and $4.2 \%$ for land, building and civil work, machinery and equipment, office furniture/fixture and intangible assets respectively.

Table 5 presents total annual working capital. The total annual working capital is the amount needed to run the business for the year. This was computed to be $\$ 503.455 .39$. Raw materials requirement had the highest contribution of $79.2 \%$, while administrative and contingencies had the least of $0.2 \%$. Percentage contributions for auxiliaries and labour are $6.7 \%$ and $13.9 \%$ respectively.

The total investment cost was computed to be $\$ 507,321$ as presented in Table 6. This is the amount required to start up the business. Fixed capital amounted to $\$ 339,502.76$, while working capital amounted to $\$ 167,818.46$. The working capital is the cost of input materials required to operate the plant for the first quarter. 
Table 6. Total Capital Investment.

\begin{tabular}{ccc}
\hline S/N & Item & Cost $(\$)$ \\
\hline 1 & Fixed Capital & $339,502.76$ \\
2 & Working Capital & $167,818.46$ \\
Total & & $\mathbf{5 0 7 , 3 2 1 . 2 3}$ \\
\hline
\end{tabular}

\subsection{Financial Analysis}

Financial analysis was carried out to determine whether the investment is stable and profitable to warrant a monetary investment. The net profit ratio, rate of return and the payback period were used to determine the profitability of the investment.

\subsubsection{Total Annual Production}

Annual production cost is the summation of total recurring cost, all depreciations and interest on total investment. Table 7 presents total annual production cost.

\subsubsection{Total Annual Returns}

Gate cost per $50 \mathrm{~kg}$ pozzolana put at $\$ 2.21$.

A total annual sale projected at 300,000 of $50 \mathrm{Kg}$ bags gives $\$ 662,983.43$.

\subsubsection{Net Profit Per Annum (NP/A)}

$$
N P / A=\text { Total returns }- \text { cost of production }=\$ 107,961.70
$$

\subsubsection{Net Profit Ratio (NPR)}

$$
N P R=(\text { Net profit per annum/annual returns }) \times 100=16.28 \%
$$

\subsubsection{Rate of Return (RR)}

$R R=($ Net profit per annum/total investmen $\mathrm{t}) \times 100=21.28 \%$

\subsubsection{Payback Period (PP)}

$$
P P=(\text { Total investment } / \text { total annual net profit })=4.7 \text { years }
$$

Table 7. Total annual production cost.

\begin{tabular}{ccc}
\hline S/N & Item & Cost $(\$)$ \\
\hline 1 & Total recurring cost & $503,455.39$ \\
2 & Depreciation on machine/equipment & $10,337.02$ \\
3 & $5 \%$ & $21,71.27$ \\
4 & Depreciation on office equipment $10 \%$ & $39,058.06$ \\
& Total interest on loan $10 \%$ & \\
Total & & $\mathbf{5 5 5 , 0 2 1 . 7 3}$ \\
\hline
\end{tabular}

${ }^{*}$ Interest rate of $10 \%$ assuming $40 \%$ equity and $60 \%$ loan. 
Total annual sale is computed to be $\$ 662,983.43$ assuming a gate price of $\$ 2.21$ per bag and a total annual sale of 300,000 bags. The net annual profit is given to be $\$ 107,961.70$ as reflected in Equation (1). The profit on the investment over a period of time (Rate of Return) is computed as $21.28 \%$ using Equation (3). The payback period which is the time required to recoup the total investment was obtained as 4.7 years.

\section{Conclusion}

The business is technically viable based on the calculation and with raw material spread across different parts of the country. The technology involved is the Vertical Shaft Kiln based technology which is the most viable for mini/small scale ventures. The total investment cost is estimated to be $\$ 507,321.23$ and a payback period of 4.7 years. The analysis shows that the business is viable and capable of creating an avenue for investment in the area of pozzolana production in Nigeria. The business can generate employment for 40 persons on site outside the indirect employment generation based on this plant size. All financial outlays and outcomes presented in this profile are based on the estimated production size or capacity. Using this presentation as a guide, investors are however encouraged or advised to conduct its own feasibility study for a given production capacity and plant size as well as site location.

\section{Conflicts of Interest}

The authors declare no conflicts of interest regarding the publication of this paper.

\section{References}

[1] Hossain, M.A., Rashid, M.H., Mohammed, R.M. and Laz, O.U. (2011) Performance Concrete in Presence of Supplementary Cementitious Material. International Journal of Civil \& Environmental Engineering IJCEE, 11, 60-66.

[2] Opeyemi, J., Danladi, S.M., Tolulope, D.A., Kolapo, O.O., Ayodele, S.O. and Razaq, R.B. (2018) Development of a Fully Pozzolanic Binder for Sustainable Construction: Whole Cement Replacement in Concrete Applications. International Journal of Civil Engineering and Technology, 9, 1-12.

[3] Crow, J.M. (2008) The Concrete Conundrum. Chemistry World, 62. http://www.rsc.org/images/Construction tcm18-114530.Pdf https://doi.org/10.1201/b12851-5

[4] Neuwald, A.D. (2004) Supplementary Cementitious Material. Part 2; Pozzolanic Supplementary Cementitous Materials, in Manufactured Concrete Magazine. 17. http://www.precast.org/publicationns/mc/2005-janfeb/scmpart2

[5] Mehta, P.K. (1987) Natural Pozzolans: Supplementary Cementing Materials in Concrete. CANMET Special Publication, 86, 1-33.

[6] Snellings, R., Mertens, G. and Elsen, J. (2012) Supplementary Cementous Materials. Reviews in Mineralogy and Geochemistry, 74, 211-278. https://doi.org/10.2138/rmg.2012.74.6 
[7] Idorn, M.G. (1997) Concrete Progress from the Antiquity of the Third Millennium. Telford, London. https://doi.org/10.1680/cpftatttm.26315

[8] Moore, D. (1995) The Riddle of Ancient Roman Concrete. Newsletter of the US Department of the Interior, Bureau of Reclammation, Upper Colorado Region. http://www.romanconcrete.com/

[9] Gourichon, H. (2013) Analysis of Incentives and Disincentives for Oil Palm in Nigeria Technical Notes Series, Monitoring African Food and Agricultural Policies (MAFAP), Food and Agriculture Organization (FAO) of the United Nations, Rome.

[10] United Nations Centre for Human Settlement (1992) Mini Cement Production. Journal of the Network of African Countries in Local Building Materials and Technology, 2, 29-34.

[11] Nduka, D.O. and Ogunsanmi, O.E. (2015) Construction Professionals' Perception on Green Building Awareness and Accruable Benefits in Construction Projects in Nigeria. Covenant Journal of Research in the Built Environment, 3, 30-52.

[12] Ayininuola, G.B. and Adekitan, O.A. (2016) Characterization of Ajebo Kaolinite Clay for Production of Natural Pozzolan. International Journal of Civil, Environmnetal, Structural, Construction and Engineering, 10, 1212-1219.

[13] Joshua, O., Ogunde, A.O., Omuh, I.O., Ayegba, C. and Olushola, K.O. (2015) Exploring the Pozzolanic Potential of Blend of Palm Kernel Nut Ash (PKNA) with Cement towards a Sustainable Construction. Proceedings of the Covenant University International Conference on Africa Development Issue (CU-ICADI), No. 2, 135-140. 